\title{
Aglaenita (Hemiptera: Cicadellidae: Neocoelidiinae): a new species from Brazil
}

\author{
Ana Paula Marques-Costa
}

\author{
Laboratório de Entomologia, Departamento de Biologia, Universidade Federal de Sergipe. Avenida Marechal Rondon, Jardim \\ Rosa Elze, 49100-000 São Cristóvão, SE, Brazil.E-mail: apmc@ufs.br
}

\begin{abstract}
Aglaenita Spinola, 1850 comprises fourteen species, all occurring in Brazil, including a new species, A. hambletoni sp. nov., which is described herein. The genus is close to Biza Walker, 1858 and Megacoelidia Kramer \& Linnavuori, 1959. Aglaenita hambletoni sp. nov. can be distinguished from other Aglaenita species mainly by the characters of male genitalia, especially by the pygofer bearing an apical bifurcated process, the branches of the process pointed and sclerotized, the upper branch longer than the lower, tooth-like one; and by the aedeagus without processes and with the ventral margin without teeth. The diagnosis of the genus and the known geographical distribution of its species are also given.
\end{abstract}

KEY WORDS. Geographical distribution; leafhoppers; neocoelidiines; new species; taxonomy.

Neocoelidiinae comprises 169 valid species in 32 genera (Marques-Costa \& Cavichioli 2009a, b). The subfamily is mainly Neotropical, with only four genera recorded from the Nearctic Region: Coelella DeLong, 1953, Neocoelidia Gillette \& Baker, 1895, Cocoelidia DeLong, 1953, and Neocoelidiana DeLong, 1953 (Nielson \& KNIGHT 2000).

Aglaenita was described by Spinola (1850a, b), who designated Aglenita [sic] bipunctata Spinola, 1850, as the type-species. According to the label, the type-locality of this type is "Brésil, Cayenne". Spinola (1850a, b) spelled the genus name in two different ways: Aglaenita and Aglenita. Latter, CAVICHIoli (1999) redescribed the genus and discussed the double spelling of the generic name, which had been questioned by Oman et al. (1990). Following the rules of the International Code of Zoological Nomenclature (ICZN 1999), the correct spelling is the original one (Aglaenita), used in the manuscript of SpInola (1850a). In the same article, Cavichioli (1999) transferred Aglaenita to the Neocoelidiinae. The taxonomic position of the genus, before Cavichioli (1999), had been either uncertain (Evans 1947) or the genus was included in the Idiocerinae (Metcalf 1966).

Chiamolera \& Cavichioli (2003) included three species in Aglaenita: A. similis Chiamolera \& Cavichioli, 2003, A. elegans Chiamolera \& Cavichioli, 2003, and A. dubia Chiamolera \& Cavichioli, 2003. They provided new geographical records for A. bipunctata. Later, MARQUes-Costa \& CAVICHIOli (2006) described nine species in the genus and constructed a phylogenetic hypothesis for the included species, using cladistics. The cladistic analysis, based on morphological characters, had two species of Biza as outgroups. Aglaenita was recovered as a monophyletic genus based on the following synapomorphies: 1) surface of crown flattened; 2) lateral margins of crown, adjacent to compound eyes, slightly or moderately carinate; 3 ) crown median length approximately two-thirds of interocular width; and 4) ventral margin of aedeagus with teeth. However, some of these features vary within the genus. MARQUES-COSTA \& CAVICHIOLI (2006) also provided an identification key to the species of Aglaenita and described the female of $A$. elegans for the first time.

Analysis of a specimen from the state of Minas Gerais (Brazil) deposited at the United States National Museum (USNM), Washington, D.C., revealed that it was an undescribed species of Aglaenita and also a new state record for the genus. In this contribution, I describe this new species, provide a diagnosis for the genus, and list the known geographical distribution of its species. The genus comprises now fourteen valid species (Marques-Costa \& CAVICHIOLI 2006), all of which occur in Brazil (Tab. I).

\section{MATERIAL AND METHODS}

For the analysis of the genital structures, the abdomen was removed and placed in hot $10 \% \mathrm{KOH}$, following OMAN (1949), with small modifications in heating time (decreased to about 3-5 minutes). Softened genitalia were washed for 5-10 minutes in hot water and placed on a concave slide with Johnson $\&$ Johnson ${ }^{\circledR}$ K-Y gel to maintain the desired position for the illustrations. Genitalia were washed in hot water to remove excess K-Y gel. Dissected structures were kept in microvials with glycerin, and pinned together with the specimen. The forewing was illustrated directly from the specimen, to avoid having to remove it from the holotype. Illustrations were made using a camera lucida attached to a Wild M3Z stereoscopic microscope. The smaller structures of the genitalia were drawn using a Zeiss compound microscope, also coupled with a camera lucida. The type was photographed using Automontage image-capturing 
computer software in conjunction with a Wild Photomicroscope M400 with a JVC digital camera KY-F70 attached.

The descriptive terminology follows primarily KRAMER (1964) and Young $(1968,1977,1986)$, except for terms pertaining the head structures, which follow Hamilton (1981); and the wing venation, which follow Cом⿰тоск \& NeEDHAm (1898, 1899) and OMAN (1949). Information given within square brackets, corresponds to personal observations or additional data that are not present on the specimen labels.

\section{TAXONOMY}

\section{Aglaenita Spinola, 1850}

Aglaenita Spinola, 1850a: 59 (key); Neave, 1939: 89 (list of genera); Metcalf, 1966: 233 (catalogue); Young, 1977: 286; Oman et al., 1990: 187, 290 (catalogue); Cavichioli, 1999: 190 (redescription); Chiamolera \& Cavichioli, 2003: 379. 383 (history, key to species); Marques-Costa \& Cavichioli, 2006: 355-378 (revision, key to species, phylogeny).

Aglenita [sic] Spinola, 1850b: 132 (description); Schulze et al., 1926: 84 (list of genera); Neave, 1939: 90 (list of genera); Evans, 1947: 251 (checklist, genus of uncertain position); Metcalf, 1966: 233 (catalogue); Oman et al., 1990: 187, 290 (catalogue).

Type-species: Aglenita [sic] bipunctata Spinola, 1850, by original designation.

Diagnosis. Crown flattened, generally with two small round spots at the center, similar to ocelli (except in $A$. tridentata Marques-Costa \& Cavichioli, 2006 and A. spatulata Marques-
Costa \& Cavichioli, 2006); transverse carina present on transition between crown and frons; lateral margins, adjacent to compound eyes, carinate; anterior margin of crown, in dorsal view, slightly angulated; ocelli on anterior margin of head, on transition between crown and frons; rectangular clypeus, with parallel lateral margins and with slight apical gibbosity; posterior margin of pronotum emarginated and V-shaped; forewing venation distinct, with four apical cells and three anteapical cells; hindwings with $\mathrm{R}_{4+5}$ and $\mathrm{M}_{1+2}$ convergent before apex, fused apically, forming a single vein; male genitalia: aedeagus generally with membranous basal area.

\section{Aglaenita hambletoni sp. nov.}

Figs 1-14

Diagnosis. Male genitalia: pygofer (Fig. 5) enlarged basally, narrowed towards apex, bearing apical bifurcated process, branches of process pointed and sclerotized, upper branch longer than tooth-like lower one; aedeagus (Figs 10 and 11) without processes, basal half enlarged and membranous, shaft curved dorsally, narrowed towards apex, ventral margin without teeth.

Measurements (mm). Male holotype: total length 10.10; crown median length 0.60 ; transocular width 1.76 ; interocular width 0.96 ; frons basal width 0.68 ; frons length 1.16 ; pronotum median length 0.80 ; width between humeri 2.48 ; mesonotum median length 1.52 ; mesonotum maximum width 1.68 ; forewing length 8.08; forewing maximum width 2.62.

Description. External morphological characters as in generic description (Marques-Costa \& CAVICHIOLI 2006), except:

Table I. Species included in Aglaenita and their known geographical distribution (Brazilian states and French Guiana department inside parenthesis).

\begin{tabular}{ll}
\multicolumn{1}{c}{ Species } & \multicolumn{1}{c}{ Geographical distribution } \\
\hline A. affinis Marques-Costa \& Cavichioli, 2006 & Brazil (Roraima and Amazonas) \\
A. bicornis Marques-Costa \& Cavichioli, 2006 & Brazil (Amazonas) \\
A. bifurcata Marques-Costa \& Cavichioli, 2006 & Brazil (Mato Grosso) \\
A. bipunctata Spinola, 1850 & Brazil (Mato Grosso) and French Guiana (Guyane) \\
A. coariensis Marques-Costa \& Cavichioli, 2006 & Brazil (Amazonas) \\
A. dubia Chiamolera \& Cavichioli, 2003 & Brazil (Rio de Janeiro) \\
A. elegans Chiamolera \& Cavichioli, 2003 & Brazil (Mato Grosso) \\
A. hambletoni sp. nov. & Brazil (Minas Gerais) \\
A. longicornis Marques-Costa \& Cavichioli, 2006 & Brazil (Amazonas) \\
A. similis Chiamolera \& Cavichioli, 2003 & Brazil (Amazonas) \\
A. spatulata Marques-Costa \& Cavichioli, 2006 & Brazil (Mato Grosso) \\
A. spinipenis Marques-Costa \& Cavichioli, 2006 & Brazil (Mato Grosso) \\
A. tridentata Marques-Costa \& Cavichioli, 2006 & Brazil (Mato Grosso) \\
A. unciformis Marques-Costa \& Cavichioli, 2006 & Brazil (Espírito Santo) \\
\hline
\end{tabular}




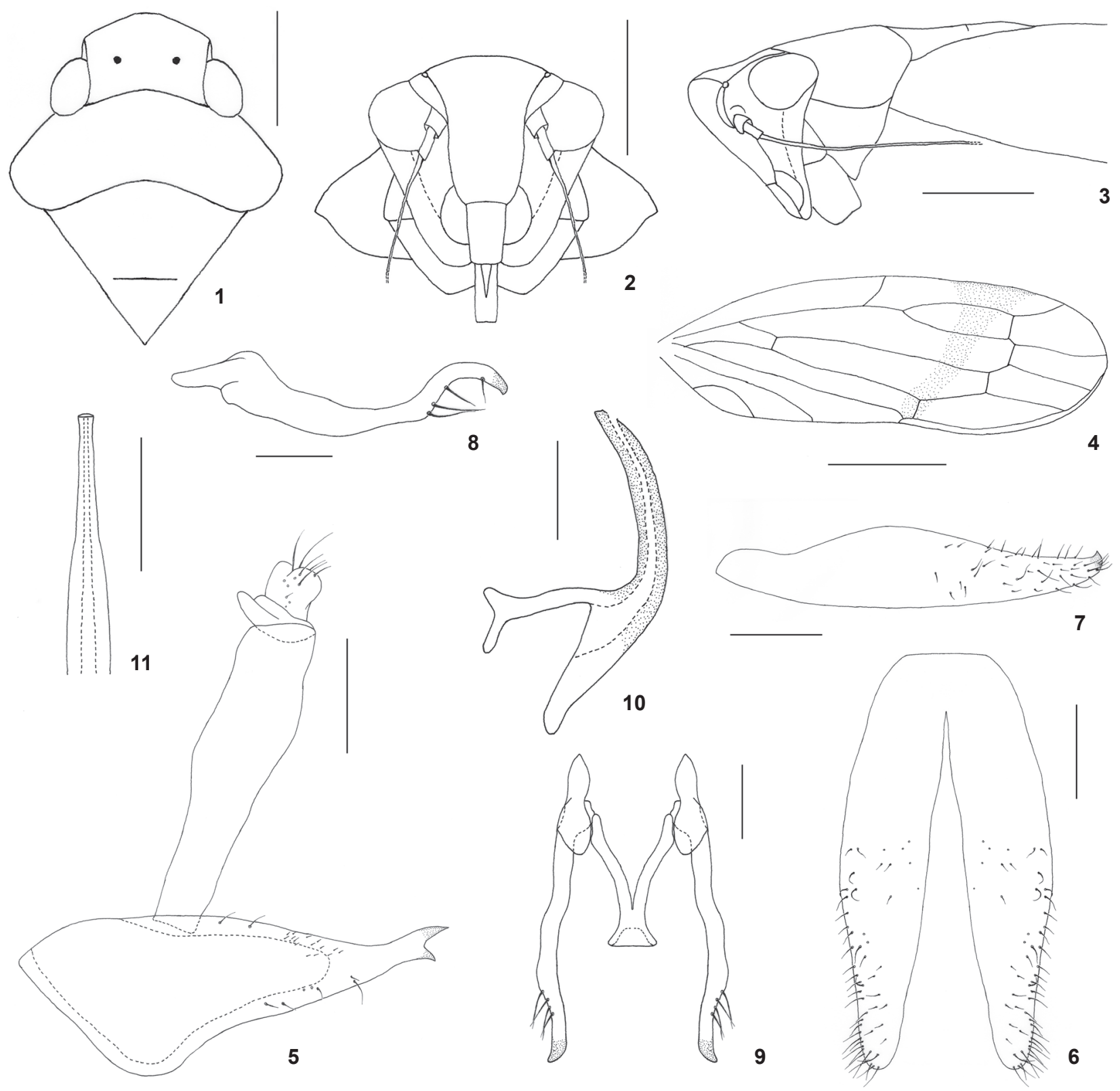

Figures 1-11, Aglaenita hambletoni sp. nov., male holotype: (1) head, pronotum and mesonotum, dorsal view; (2) head and thorax, frontal view; (3) head, thorax, forecoxa and base of forewing, lateral view; (4) forewing; (5) pygofer and anal tube, lateral view; (6) subgenital plates, ventral view; (7) subgenital plate, lateral view; (8) style, lateral view; (9) styles and connective, dorsal view; (10) aedeagus, lateral view; (11) apex of aedeagus, ventral view. Scale bars: 1-3=1.0 mm, $4=2.0 \mathrm{~mm}, 5-7=0.5 \mathrm{~mm}, 8-11=0.3 \mathrm{~mm}$.

crown median length approximately one-third of transocular width and two-thirds of interocular width; coronal suture and muscle impressions indistinct (Figs 1-3); forewings (Fig. 4) about three times longer than greatest width; base of second apical cell more basal than third and fourth ones; base of fourth apical cell slightly more basal than third; outer anteapical cell closed, inner and central ones open. Hindleg femoral formula $2+2+1$ on right leg and $2+2+1+1+1$ on left leg. Male genitalia: pygofer (Fig. 5), in lateral view, enlarged basally, narrowed towards apex; without macrosetae; bearing apical bifurcated process, branches of process pointed and sclerotized, upper branch longer than tooth-like lower one. Subgenital plates (Figs 6 and 


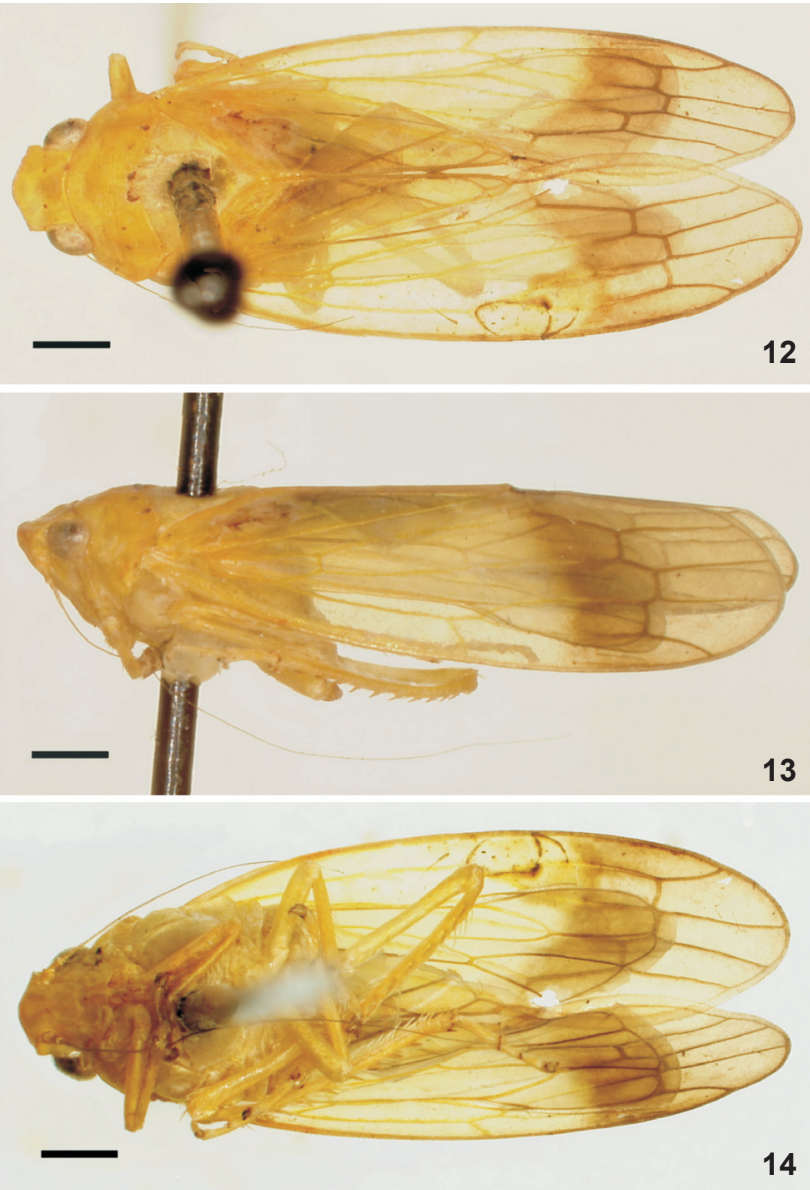

Figures 12-14, Aglaenita hambletoni sp. nov., male holotype: (12) dorsal view; (13) lateral view; (14) ventral view. Scale bars $=1.0 \mathrm{~mm}$.

7) as long as pygofer, fused only at basal sixth, approximately triangular, narrowed towards apex; with rounded apices; setae along lateral margins of median and apical thirds and apices; length of each plate about five times its basal width; in lateral view, with apical sclerotized tooth. Styles (Figs 8 and 9) long and slender; without preapical lobe; inner and outer lateral margins without undulations; apices sclerotized and hook-like, curved ventrally; with setae on ventral surface of apical region. Connective (Fig. 9) V-shaped; articulated with base of aedeagus; not bifurcated at articulation point; about half length of styles. Aedeagus (Figs 10 and 11), in lateral view, simple, without processes; basal half enlarged and membranous; shaft curved dorsally, narrowed towards apex, ventral margin without teeth, gonopore apical. Anal tube (Fig. 5) membranous, long, without processes.

General color (Figs 12-14). Yellow, without distinct marks, except for two brown spots on disk of crown, similar to ocelli, and a brown transverse stripe on forewings, extending from cla- val apex to costal margin, separating middle and apical thirds. Forewings hyaline, basal and middle thirds yellow, with yellow veins, apical third brown with brown veins. Hindwings the same color as forewings. Legs yellow with setae of same color.

Female unknown.

Specimens examined. Male holotype (USNM) with the following labels: BrasiL, [Minas Gerais], Viçosa, 13.XI.1929, E. Hambleton leg.

Holotype condition. Pinned through middle of mesonotum. Both antennal flagella partially broken. Legs and wings in perfect state, except for a small hole at base of first apical cell of the right forewing. Abdomen dissected.

Etymology. The species name refers to the collector, E. Hambleton.

Remarks. Aglaenita hambletoni sp. nov. is externally very similar to the other species of the genus. It can be distinguished mainly by the characters of male genitalia, especially those described in the diagnosis.

\section{ACKNOWLEDGMENTS}

I am grateful to Thomas Henry and Stuart McKamey for receiving me during my visit to the USNM; to Coordenação de Aperfeiçoamento de Pessoal de Nível Superior and Conselho Nacional de Desenvolvimento Científico e Tecnológico for the financial support.

\section{LITERATURE CITED}

Cavichioli, R.R. 1999. Aglaenita Spinola and A. bipunctata Spinola (Hemiptera, Auchenorrhyncha, Cicadellidae): redescription of both taxa and taxonomic notes. Revista Brasileira de Zoologia 16 (1): 189-192.

Chiamolera, L.B. \& R.R. Cavichioli. 2003. Aglaenita Spinola: descrição de três novas espécies do Brasil com chave para machos (Hemiptera, Cicadellidae, Neocoelidiinae). Revista Brasileira de Zoologia 20 (3): 379-383. doi: 10.1590/S010181752003000300003.

Comstock, J.H. \& J.G. Needham. 1898. The wings of insects. American Naturalist 32: 43-48, 81-89, 231-257, 335-340, 413-424, 561-565, 768-777, 903-911.

Сомsтоск, J.H. \& J.G. Needham. 1899. The wings of insects. American Naturalist 33: 117-126, 573-582, 845-860.

Evans, J.W. 1947. A natural classification of leafhoppers (Jassoidea, Homoptera), Part 3: Jassidae. Transactions of the Royal Entomological Society of London 98 (6): 105-271.

Hamilton, K.G.A. 1981. Morphology and evolution of the rhynchotan head (Insecta: Hemiptera, Homoptera). Canadian Entomologist 113: 953-974.

ICZN. 1999. International Code of Zoological Nomenclature. The International Trust for Zoological Nomenclature c/o The Natural History Museum, London. Available online at: http:/ /www.iczn.org/iczn/index.jsp [Accessed: 22.IX.2010].

KRAMER, J.P. 1964. A generic revision of the leafhopper subfamily 
Neocoelidiinae. (Homoptera: Cicadellidae). Proceedings of the United States National Museum 15: 259-287.

Marques-Costa, A.P. \& R.R. CAVICHIoli. 2006. Revisão taxonômica, análise cladística e descrição de espécies novas de Aglaenita Spinola (Hemiptera, Cicadellidae, Neocoelidiinae). Revista Brasileira de Entomologia 50 (3): 355-378. doi: 10.1590/ S0085-56262006000300006.

Marques-Costa, A.P. \& R.R. Cavichioli. 2009a. Nota sinonímica em Chinaia Bruner \& Metcalf (Hemiptera, Cicadellidae, Neocoelidiinae). Revista Brasileira de Entomologia 53 (1): 49-54. doi: 10.1590/S0085-56262009000100013.

Marques-Costa, A.P. \& R.R. Cavichioli. 2009b. Revalidação de Acocoelidia DeLong (Hemiptera, Cicadellidae, Neocoelidiinae). Revista Brasileira de Entomologia 53 (3): 337-343. doi: 10.1590/S0085-56262009000300005.

Metcalf, Z.P. 1966. General Catalogue of the Homoptera. Fascicle VI. Cicadelloidea. Part 16. Idioceridae. Washington, D.C., United States Department of Agriculture, Agriculture Research Service, 237p.

Neave, S.A. 1939. A-C. Nomenclator Zoologicus. A list of the names of genera and subgenera in zoology from the tenth edition of Linnaeus 1758 to the end of 1935. London, The Zoological Society of London, vol. 1, XIV+957p.

Nielson, M.W. \& W.J. KnIGHT. 2000. Distributional patterns and possible origin of leafhoppers. (Homoptera, Cicadellidae). Revista Brasileira de Zoologia 17: 81-156.

Oman, P.W. 1949. The Nearctic leafhoppers (Homoptera: Cicadellidae). A generic classification and check list. Memoirs of the Entomological Society of Washington 3: 1-253.

Submitted: 22.IX.2010; Accepted: 28.XI.2010.

Editorial responsibility: Gabriel L.F. Mejdalani
OMAN, P.W.; W.J. Knight \& M.W. Nielson. 1990. Leafhoppers (Cicadellidae). A bibliography, generic check-list and index to the World literature 1956-1985. London, C.A.B. International Institute of Entomology, 368p.

SChUlzE, F.E.; W. KÜKenthal \& K. Heider. 1926. A-Anj. Nomenclator Animalium Generum et Subgenerum. Auftrage der Preussischen Akademie der Wissenschaften zu Berlin 1 (1): $1-160$.

SPINOLA, M. 1850a. Tavola sinottica dei generi spettanti alla classe degli insetti artroidignati, Hemiptera, Linn. Latr. - Rhyngota, Fab. - Rhyncota, Burm. Memorie di Matematica e di Fisica della Società Italiana delle Scienze Residente in Modena 25 (1): 1-60.

SpInola, M. 1850b. Di alguni generi d'insetti artroidignati nuovamente proposti dal socio attuale Signor Marchese Massimiliano Spinola nella sua tavola sinottica di questo ordine che precede la presente memoria. Memorie di Matematica e di Fisica della Società Italiana delle Scienze Residente in Modena 25 (1): 61-138.

Young, D.A. 1968. Taxonomic study of the Cicadellinae (Homoptera, Cicadellidae). Part 1. Proconiini. Bulletin of the United States National Museum 261: 1-287.

Young, D.A. 1977. Taxonomic study of the Cicadellinae (Homoptera: Cicadellidae) Part 2. New World Cicadellini and genus Cicadella. Bulletin of the North Carolina Agricultural Experiment Station 239: VI+1135p.

Young, D.A. 1986. Taxonomic study of the Cicadellinae (Homoptera: Cicadellidae) Part 3. Old World Cicadellini. Bulletin of the North Carolina Agricultural Experiment Station 281: 1-639. 